\title{
Current advancements in assay technologies and strategies to enable drug discovery \\ Supplemental Material
}

Scott A. Busby ${ }^{1}$, Seth Carbonneau ${ }^{1}$, John Concannon ${ }^{1}$, Christoph E. Dumelin ${ }^{2}$, YounKyoung Lee ${ }^{1}$, Shin Numao $^{2}$, Nicole Renaud ${ }^{1}$, Thomas M. Smith ${ }^{1}$, Douglas S. Auld ${ }^{1 *}$.

AUTHOR ADDRESS: 'Novartis Institutes for Biomedical Research, Chemical Biology and Therapeutics, 250 Mass. Ave., Cambridge, MA. ${ }^{2}$ Novartis Institutes for Biomedical Research, 4056 Basel, Switzerland 


\section{Supplementary Table 1}

\begin{tabular}{|c|c|c|c|c|}
\hline Technology & $\begin{array}{l}\text { Throughp } \\
\text { ut (cpds) }\end{array}$ & Typical Output & Description & Ref \\
\hline ALPHA & $10^{6}$ & $\begin{array}{l}\qquad \frac{A}{D} \\
\mathrm{~A}=\text { acceptor luminescence } \\
\mathrm{D}=\text { donor luminescence } \\
\text { Chemiluminescence signal } \\
\lambda_{\mathrm{ex}}=680 \mathrm{~nm}, \lambda_{\mathrm{em}}=520-620 \mathrm{~nm}\end{array}$ & $\begin{array}{l}\text { Amplified luminescent proximity } \\
\text { homogeneous assay. Detection is based } \\
\text { on singlet oxygen production }(\sim 60,000 \\
\text { molecules/sec) upon laser excitation of } \\
\text { ALPHA beads; capable of measuring } \\
\text { interactions with distances } \sim 10 x \text { larger } \\
\text { than FRET pairs }(\sim 200 \mathrm{~nm}) \text {. Further } \\
\text { described in main text. }\end{array}$ & 1 \\
\hline AS/MS & $10^{4}-10^{5}$ & $\begin{array}{l}\qquad \frac{A}{I} \\
\text { A= Area of analyte Peak } \\
\mathrm{I}=\text { Area of internal standard (IS) peak } \\
\text { Output is Area ratio of Analyte/IS }\end{array}$ & $\begin{array}{l}\text { Compounds bound to protein elute in } \\
\text { protein fraction of SEC column and then } \\
\text { are analyzed in RP-HPLC following } \\
\text { release from protein. Compounds } \\
\text { quantitated as ratio of area under curve } \\
\text { for mass peak of analyte and area under } \\
\text { curve for mass peak of internal standard. } \\
\text { Further described in main text. }\end{array}$ & 2,3 \\
\hline Biodesy & $10^{4}-10^{5}$ & $\begin{array}{l}\Delta \mathrm{SH}=\frac{I_{t \max -I_{t 0}}}{I_{t 0}} \\
\mathrm{SH}=\text { second harmonic intensity } \\
\mathrm{I}_{\mathrm{t} 0}=\mathrm{SH} \text { intensity measured just before } \\
\text { injection of test solution } \\
\mathrm{I}_{\text {tmax }}=\mathrm{SH} \text { intensity measured at desired } \\
\left.\text { detection time ( } \mathrm{t}_{\max }\right) \\
\text { Laser excitation of a protein bound to a } \\
\text { surface creates an evanescent wave } \\
\text { through total internal reflection }\end{array}$ & $\begin{array}{l}\text { Second harmonic generation (SHG) is the } \\
\text { conversion of two photons of equal } \\
\text { energy to one photon of twice the energy, } \\
\text { produced by a dye molecule bound to a } \\
\text { surface. Proteins are labeled with } \\
\text { proprietary dyes and bound to a plate } \\
\text { surface containing a lipid bilayer. SHG } \\
\text { efficiency is dependent on the orientation } \\
\text { of the dye to the } Z \text {-axis normal to the } \\
\text { surface. Changes in SH signal, measured } \\
\text { in real time, are reflective of } \\
\text { conformational changes due to, for } \\
\text { example, ligand binding. }\end{array}$ & 4 \\
\hline BRET & $10^{6}$ & $\begin{array}{l}\qquad \frac{A}{D} \\
\text { A }=\text { acceptor luminescence } \\
\mathrm{D}=\text { donor luminescence } \\
\mathrm{A}=\text { GFP emission, HaloTag } \\
\mathrm{D}=\text { emission from Renilla reniformis } \\
\text { luciferase (RLuc) and variants or } \\
\text { NanoLuc }\end{array}$ & $\begin{array}{l}\text { Bioluminescence resonance energy } \\
\text { transfer. Optimized RLuc/GFP BRET } \\
\text { uses coelenterazine } 400 \text { a (DeepBlueC) as } \\
\text { substrate for RLuc or a variant of RLuc } \\
\text { known as RLuc8, emitting at a } \\
\text { wavelength to excite GFP if in close } \\
\text { proximity (<10nm). See also NanoBRET } \\
\text { below. }\end{array}$ & 5 \\
\hline CETSA & $10^{2}-10^{3}$ & $\begin{array}{l}\mathrm{T}_{\text {agg }}=\text { thermal aggregation temperature } \\
\text { taken as the midpoint of an assay curve } \\
\text { measuring the native amount of protein } \\
\text { remaining in a sample. }\end{array}$ & $\begin{array}{l}\text { Cellular Thermal Shift Assay. Ligands } \\
\text { that bind to proteins can stabilize the } \\
\text { native state to thermal melting in cells; } \\
\text { unfolded protein becomes irreversibly } \\
\text { aggregated. High-throughput analysis is } \\
\text { provided by Pelagobio using ALPHA } \\
\text { technology as the readout }\end{array}$ & 6,7 \\
\hline DSF & $10^{4-} 10^{5}$ & $\begin{array}{l}\Delta \mathrm{T}_{\mathrm{m}}=\mathrm{T}_{\mathrm{m}(\text { protein +ligand) }}-\mathrm{T}_{\mathrm{m}(\text { protein }+\mathrm{DMSO})} \\
\mathrm{T}_{\mathrm{m}} \text { values are calculated from the RFUs } \\
\text { vs temperature plots using semi- } \\
\text { parametric fitting functions }\end{array}$ & $\begin{array}{l}\text { Differential scanning fluorimetry. } \\
\text { Compounds that bind to a protein may } \\
\text { stabilize or destabilize the protein leading } \\
\text { to changes in melting temperature }\left(\mathrm{T}_{\mathrm{m}}\right) \text {. } \\
\text { In DSF thermal denaturation is }\end{array}$ & 8 \\
\hline
\end{tabular}




\begin{tabular}{|c|c|c|c|c|}
\hline & & $\begin{array}{l}\text { Employs solvatochromatic dyes such as } \\
\text { Sypro Orange or 1-anilinonaphthalene- } \\
\text { 8-sulfonic acid (1,8-ANS) that show } \\
\text { high fluorescence in low dielectric } \\
\text { environments provided by hydrophobic } \\
\text { regions such as those exposed during } \\
\text { proteins thermal denaturation. }\end{array}$ & $\begin{array}{l}\text { understood as an equilibrium process } \\
\text { unlike CETSA described above. }\end{array}$ & \\
\hline ESC & & Human embryonic stem cells & $\begin{array}{l}\text { Exhibit a pluripotent state capable of } \\
\text { differentiation into any cell type. }\end{array}$ & 9 \\
\hline $\begin{array}{l}\text { Fluorescent } \\
\text { protein } \\
\text { reporters }\end{array}$ & & $\begin{array}{l}\text { Particularly enabling to HCI and HT-FC } \\
\text { screens is the use of fluorescent proteins } \\
\text { such as GFP and RFP } \\
\text { Proteins tagged with fluorescent protein } \\
\text { enable imaging of live, intact cells for protein } \\
\text { abundance and disruptions in localization as } \\
\text { well as flow cytometry applications } \\
\text { Use of ratiometric data with bi bicistronic } \\
\text { expression vectors can be a way de-coupling } \\
\text { target-specific abundance from off-target } \\
\text { cellular effects }\end{array}$ & $\begin{array}{l}\text { Fluorescent reporter proteins Multiple } \\
\text { applications in imaging and flow cytometry. } \\
\text { For measuring protein abundance, bicistronic } \\
\text { expression vectors are useful that use a single } \\
\text { promoter to express the target protein tagged } \\
\text { fluorescent protein (such as GFP) and } \\
\text { another untagged fluorescent protein with } \\
\text { non-overlapping spectra (such as RFP) } \\
\text { separated either a IRES or ribosomal skipping } \\
\text { sequence such as P2A. Untagged fluorescent } \\
\text { protein serves as an internal control for off- } \\
\text { target effects and the tagged-target can be } \\
\text { normalized to the untagged to quantify target } \\
\text { abundance }\end{array}$ & $10-13$ \\
\hline FLT & $10^{5}-10^{6}$ & $\begin{array}{l}\text { Fluorescent lifetime }(\tau) \text { calculated from } \\
\text { measuring relative fluorescent units } \\
\text { (RFUs) over time (nsec timescale) and } \\
\text { fitting to the first order equation } \\
\qquad A_{t}=A_{o} e^{=k t} \\
\mathrm{~A}_{\mathrm{t}}=\text { RFUs at time } \mathrm{t} \\
\mathrm{A}_{\mathrm{o}}=\text { RFUs at time zero } \\
\mathrm{k}=\text { decay constant } \\
\tau=\frac{1}{K}\end{array}$ & $\begin{array}{l}\text { Fluorescent Life Time. Use of fluorescent } \\
\text { probes such as 9-aminoacridine with long } \\
\text { fluorescent lifetimes in the } \sim 20 \text { nsec range } \\
\text { to measure changes in the fluorescent } \\
\text { decay curve. Protein-ligand binding and } \\
\text { enzymatic assays are enabled in } 384 \text {-well } \\
\text { and 1536-well plates. }\end{array}$ & 14 \\
\hline FP & $10^{6}$ & $\begin{array}{l}\quad m P=\left[\frac{(S-P x G)}{(S+P x G)}\right] x 100 \\
\mathrm{mP}=\text { millipolarization } \\
\mathrm{G}=\text { correction factor for fluorescent } \\
\text { reader calibrated relative to a known } \\
\text { standard } \\
\mathrm{S}=\text { light parallel to excitation plane } \\
\mathrm{P}=\text { light perpendicular to excitation } \\
\text { plane } \\
\text { Also useful is the anisotropy (a) as this } \\
\text { is related to the total fluorescent } \\
\text { intensity of the sample (denominator } \\
\text { below) } \\
\qquad a=\frac{P-S}{S+2 P}\end{array}$ & $\begin{array}{l}\text { Fluorescence polarization. Polarized } \\
\text { light is used to detect how rapidly a } \\
\text { fluorophore is tumbling. For standard } \\
\text { fluorophores with nsec lifetimes, small } \\
\text { fluorescently labeled ligands } \\
\text { (e.g. }<2,000 \mathrm{Da} \text { ) will show low } \\
\text { polarization while if this ligand binds to a } \\
\text { large receptor ( }>10,000 \mathrm{Da} \text { ) the } \\
\text { polarization will increase. Fluorescent } \\
\text { compound interference can be identified } \\
\text { by plotting the anisotropy vs the total } \\
\text { fluorescent intensity of the sample - } \\
\text { genuine actives should not affect the total } \\
\text { fluorescent intensity relative to control } \\
\text { (vehicle-only) samples. }\end{array}$ & 15 \\
\hline
\end{tabular}




\begin{tabular}{|c|c|c|c|c|}
\hline FRET & $10^{6}$ & $\begin{array}{l}\qquad \frac{A}{D} \\
\mathrm{~A}=\text { acceptor fluorescence } \\
\mathrm{D}=\text { donor fluorescence }\end{array}$ & $\begin{array}{l}\text { Förster resonance energy transfer. } \\
\text { Efficiency is dependent on orientation } \\
\text { and distance based on dipole-dipole } \\
\text { interactions and falls off as } \sim \frac{1}{r^{6}}, \text { range is } \\
<10 \mathrm{~nm} \text {. Further described in main text. }\end{array}$ & 16 \\
\hline TR-FRET & $10^{6}$ & $\begin{array}{l}\qquad \frac{A}{D} \\
\text { A = acceptor fluorescence } \\
\mathrm{D}=\text { donor fluorescence } \\
\mathrm{Tb}^{2+-} \text { cryptates: } \\
\lambda_{\mathrm{ex}}=340 \mathrm{~nm} \lambda_{\mathrm{em}}=520 \mathrm{~nm}(\text { Alexa488) } \\
\lambda_{\mathrm{ex}}=340 \mathrm{~nm} \lambda_{\mathrm{em}}=665 \mathrm{~nm}(\mathrm{~d} 2) \\
\mathrm{Eu}^{3+} \text {-cryptates: } \\
\lambda_{\mathrm{ex}}=340 \mathrm{~nm} \lambda_{\mathrm{em}}=665 \mathrm{~nm}(\text { Alexa647, } \\
\text { Atto647, d2) }\end{array}$ & $\begin{array}{l}\text { Time resolved-FRET. As described } \\
\text { above but detection involves the use of } \\
\text { lanthanides as the donor fluorophore } \\
\text { with long fluorescent lifetimes allowing } \\
\text { the FRET signal to be detected } ~ 50- \\
100 \mu \text { sec after the excitation light is } \\
\text { turned off. Further described in main } \\
\text { text. }\end{array}$ & 17 \\
\hline HCS/HCI & $10^{5}-10^{6}$ & $\begin{array}{l}\text { Gray-scaled values for intensity } \\
\text { measurements, degree of object } \\
\text { overlap/co-localization, as well as } \\
\text { granular, broadly descriptive object and } \\
\text { image-based features such as object } \\
\text { size, shape, and texture can also be } \\
\text { collected, and used to perform high } \\
\text { dimensional morphological analysis }\end{array}$ & $\begin{array}{l}\text { High Content Screening or High Content } \\
\text { Imaging. Enabled with high-throughput } \\
\text { automated microscopes. Wide field and } \\
\text { confocal methods are widely applied in } \\
\text { HTS (Supplementary Table 2). Digital } \\
\text { images are obtained by illuminating } \\
\text { samples with specific wavelengths of } \\
\text { light using a microscope objective and } \\
\text { projecting the magnified image onto a } \\
\text { highly sensitive digital camera. Images } \\
\text { are typically analyzed via segmentation } \\
\text { and feature extraction algorithms or } \\
\text { Machine Learning models. Further } \\
\text { described in main text }\end{array}$ & 18,19 \\
\hline HT-LC/MS & $10^{4}-10^{5}$ & $\begin{array}{l}\qquad \frac{A}{I} \\
\text { A= Area of analyte Peak } \\
\mathrm{I}=\text { Area of internal standard (IS) peak } \\
\text { Output is Area ratio of Analyte/IS }\end{array}$ & $\begin{array}{l}\text { Rapid-Fire MS platforms are most } \\
\text { common LCMS platform used currently. } \\
\text { Format is } 384 \text { so throughput is limited } \\
\text { but analytes quantitated by ratiometric } \\
\text { analysis of Area of analyte peak } \\
\text { compared to Area of internal standard } \\
\text { peak for every injection. Multiple peaks } \\
\text { can be followed per analysis providing } \\
\text { many simultaneous label-free readouts }\end{array}$ & 20 \\
\hline HT-FC & $10^{4-} 10^{6}$ & $\begin{array}{l}\text { Often used is the mean fluorescent } \\
\text { intensity (MFI) within gated } \\
\text { populations expressed as the frequency } \\
\text { of parent }=\text { number of cells in the in a } \\
\text { subpopulation/number of cells in the } \\
\text { direct parent population. }\end{array}$ & $\begin{array}{l}\text { High-throughput flow cytometry. Up to } \\
\text { 50K wells/day. Throughput/scale } \\
\text { dependent on protocol }- \text { sampling } \\
\text { volume and sipper speed. }\end{array}$ & 21,22 \\
\hline HT-qPCR & $10^{5}$ & $\begin{array}{l}\mathrm{C}_{\mathrm{t}}=\text { cycle threshold value, number of } \\
\mathrm{PCR} \text { cycles required for the fluorescent } \\
\text { signal to cross a threshold value. } \\
\left.\Delta \mathrm{C}_{\mathrm{t}}=\mathrm{Ct} \text { (test gene }\right)-\mathrm{Ct}(\text { control gene })\end{array}$ & $\begin{array}{l}\text { High throughput quantitative polymerase } \\
\text { chain reaction. PCR reaction measured } \\
\text { using either SYBR green or TaqMan } \\
\text { methods. For an optimized PCR assay, a } \\
\text { two-fold change in RQ can be considered } \\
\text { significant. }\end{array}$ & \\
\hline
\end{tabular}




\begin{tabular}{|c|c|c|c|c|}
\hline & & $\begin{array}{l}\Delta \Delta \mathrm{C}_{\mathrm{t}}=\Delta \mathrm{Ct}(\text { sample })-\Delta \mathrm{Ct} \text { (above) } \\
\mathrm{RQ}=\text { relative quantification, e.g. } \\
\text { relative to a control }=2^{-\Delta \Delta \mathrm{Ct}}\end{array}$ & & \\
\hline iPSC & & $\begin{array}{l}\text { induced pluripotent stem cells (iPSCs) } \\
\text { can be created from somatic cells such } \\
\text { as fibroblasts or peripheral blood } \\
\text { mononuclear cells by expression of } \\
\text { transgenes that control cell } \\
\text { reprogramming (c-Myc, Oct4, Sox } 2 \\
\text { and Klf4) and maintain on specialized } \\
\text { media cocktails. Current human iPSC } \\
\text { protocols appear to yeild a more } \\
\text { "primed" compared to truly pluripotent } \\
\text { ESCs }\end{array}$ & $\begin{array}{l}\text { Disease-specific iPSCs can be } \\
\text { reprogrammed from clinical patient } \\
\text { cohorts and isogenic controls which has } \\
\text { large potential to identify novel thera- } \\
\text { peutic targets and leads. Several } \\
\text { protocols have been developed to } \\
\text { differentiate hPSCs into specific cell } \\
\text { types including but not limited to: } \\
\text { neurons, hepatocytes, cardio-myocytes, } \\
\text { skeletal muscle, erythrocytes, } \\
\text { macrophages, and endothelial cells. }\end{array}$ & $24-30$ \\
\hline MALDI & $10^{6}$ & $\begin{array}{l}\qquad \frac{A}{I} \\
\mathrm{~A}=\text { Area of analyte Peak } \\
\mathrm{I}=\text { Area of internal standard (IS) peak } \\
\text { Output is Area ratio of Analyte/IS }\end{array}$ & $\begin{array}{l}\text { Pharmapulse MALDI-TOF commercial } \\
\text { platform currently the most ideal for } \\
\text { HTS applications. Format is } 1536 \text { that } \\
\text { provides highest MS throughput } \\
\text { available and analytes quantitated by } \\
\text { ratiometric analysis of Area of analyte } \\
\text { peak compared to Area of internal } \\
\text { standard MALDI not ideal for small } \\
\text { MW metabolites due to matrix } \\
\text { interference. Ideal for peptide and } \\
\text { protein assays. }\end{array}$ & 31 \\
\hline RGA & $10^{6}$ & $\begin{array}{l}\text { Either FRET, fluorescent, or } \\
\text { bioluminescence signals }\end{array}$ & $\begin{array}{l}\text { Reporter Gene Assay. Use of enzymes } \\
\text { such as luciferases or } \beta \text {-lactamase with } \\
\text { luciferins or FRET-based substrates, } \\
\text { respectively. Alternatively, fluorescent } \\
\text { proteins such as GFP to report on cellular } \\
\text { signaling events are used. }\end{array}$ & $32-34$ \\
\hline $\begin{array}{l}\text { Nano } \\
\text { luciferase }\end{array}$ & & $\begin{array}{l}\text { RLUs } \\
\text { Relative light units. } \\
\text { Bioluminescence signal }\end{array}$ & $\begin{array}{l}\text { NanoLuc, NLuc. A highly optimized } \\
\text { luciferase derived from the deep-sea } \\
\text { shrimp Oplophorus gracilirostris, a non- } \\
\text { ATP dependent luciferase }\end{array}$ & 35 \\
\hline NanoBit & $10^{6}$ & $\begin{array}{l}\text { RLUs } \\
\text { Relative light units. } \\
\text { Bioluminescence signal }\end{array}$ & $\begin{array}{l}\text { NanoLuc Binary Technology. Bright } \\
\text { luciferase, non-ATP dependent. PCA } \\
\text { enabled with a split form utilizing a } 11 \text { aa } \\
\text { N-terminal fragment. Both high affinity } \\
\text { and low affinity complementation is } \\
\text { enabled. Further described in main text. }\end{array}$ & 36 \\
\hline NanoBRET & $10^{6}$ & $\begin{array}{l}\qquad \frac{A}{D} \\
\mathrm{~A}=\text { acceptor luminescence } \\
\mathrm{D}=\text { donor luminescence } \\
\text { Bioluminescence signal. Luminescence } \\
\text { emission used to excite a fluorophore }\end{array}$ & $\begin{array}{l}\text { Bioluminescent energy transfer between } \\
\text { NanoLuc and HaloTag or labeled ligand. } \\
\text { NanoLuc provides the excitation light to } \\
\text { a red fluorescent acceptor dye. Has been } \\
\text { applied for target-engagement studies } \\
\text { using labeled ligands to various target. } \\
\text { Further described in main text. }\end{array}$ & 37,38 \\
\hline NaLTSA & $10^{2}-10^{3}$ & $\begin{array}{l}\mathrm{T}_{\mathrm{m}} \text {, from the inflection point of the } \\
\text { curve fitted to the data plotting } \\
\text { \%Stability (equation below) vs } \\
\text { Temperature. }\end{array}$ & $\begin{array}{l}\text { NanoLuc luciferase thermal shift assay. } \\
\text { Cellular protein thermal shift assay using } \\
\text { fusions of NanoLuc to a protein of } \\
\text { interest. As such, NaLTSA does not } \\
\text { require target-specific antibodies. }\end{array}$ & 39 \\
\hline
\end{tabular}




\begin{tabular}{|c|c|c|c|c|}
\hline & & $\begin{array}{l}\% \text { Stability } \\
=\frac{\left(R L U_{\text {sample }} \text { at temp }[x]\right)}{\left(R L U_{\text {sample }} \text { at temp }[\text { lowest tested }]\right.}\end{array}$ & & \\
\hline MST & $10^{4}$ & $\begin{array}{l}F_{\text {norm }}=\frac{F_{1}}{F_{2}} \\
F_{\text {norm }}=\text { normalized fluorescence } \\
F_{1}=\text { steady state fluorescence after } \\
\text { thermodiffusion } \\
F_{2}=\text { initial fluorescence or fluorescence } \\
\text { after temperature jump (to correct for } \\
\text { fluorophore temperature sensitivity) }\end{array}$ & $\begin{array}{l}\text { Microscale thermophoresis } \\
\text { Measurement of binding due to changes } \\
\text { in biomolecular size and hydration shell } \\
\text { through detecting the movement of a } \\
\text { fluorophore in a temperature gradient } \\
\text { within } \mu \mathrm{L} \text { volumes. Solvated molecules } \\
\text { are depleted in regions of elevated } \\
\text { temperature. An IR laser is used to heat a } \\
\text { microvolume of a flourophore contained } \\
\text { in a capillary and the change fluorescence } \\
\text { of fluorophore is measured. Targets are } \\
\text { measured in solution. }\end{array}$ & 40 \\
\hline $\begin{array}{l}\text { Molecular } \\
\text { Beacons }\end{array}$ & $10^{6}$ & Fluorescent intensity (FI) & $\begin{array}{l}\text { Use of a fluorophore and a corresponding } \\
\text { quencher attached to the 5' and 3' end of } \\
\text { oligonucleotides forming a hairpin } \\
\text { structure. Assays for ligases, DNA } \\
\text { polymerases, and RNA structures have } \\
\text { been developed using MB, also used in } \\
\text { the TaqMan probes for HT-qPCR }\end{array}$ & 41 \\
\hline NMR & $10^{2}$ & $\begin{array}{l}\text { Monitoring either protein chemical } \\
\text { shift perturbations or changes in } \\
\text { nuclear Overhauser effect (NOEs), } \\
\text { chemical exchange of the ligand. } \\
\text { Binding confirmation, } \mathrm{K}_{\mathrm{D}} \text {, performs } \\
\text { well for weak interactions } \mu \mathrm{M}-\mathrm{mM} \\
\text { range. } \\
\text { Applied to fragment-based drug } \\
\text { discovery }\end{array}$ & $\begin{array}{l}\text { Nuclear magnetic resonance. In drug } \\
\text { discovery techniques involve measuring } \\
\text { chemical shifts changes of protein } \\
\text { residues upon compound binding } \\
\text { including the use of }{ }^{15} \mathrm{~N} \text { labeled proteins } \\
\text { and } 2 \mathrm{D}-\mathrm{NMR} \text { (Heteronuclear Single } \\
\text { Quantum Coherence spectroscopy }-{ }^{15} \mathrm{~N} \text { - } \\
{ }^{1} \mathrm{H} \text { chemical shifts) or measuring } \\
\text { changes in ligand relaxation kinetics and } \\
\text { NOEs (waterLOGSY, Saturation } \\
\text { transfer difference, STD, NMR). }{ }^{19} \mathrm{~F}- \\
\text { NMR has also been applied to measure } \\
\text { ligand binding }\end{array}$ & $42-44$ \\
\hline SPR & $10^{2}-10^{3}$ & $\begin{array}{l}\text { Mass-based detection of biomolecular } \\
\text { interactions measured via changes in } \\
\text { refractive index on a sensor chip in real } \\
\text { time. Affinity, thermodynamic and } \\
\text { kinetic measurements are possible. } \\
\text { Response Units (RU) } \\
\mathrm{k}_{\mathrm{a}}=\text { associate constant }\left(\mathrm{M}^{-1} \mathrm{~s}^{-1}\right) \\
\mathrm{k}_{\mathrm{d}}=\text { dissociation constant }\left(\mathrm{s}^{-1}\right) \\
\mathrm{K}_{\mathrm{D}}=\text { affinity, (equilibrium } \mathrm{K}_{\mathrm{D}}=\mathrm{kd} / \mathrm{ka} \text { ), } \\
\mathrm{M}\end{array}$ & $\begin{array}{l}\text { Surface Plasmon Resonance. Targets are } \\
\text { immobilized on a sensor chip via a tag } \\
\text { (biotin, 6-His are typically used) and } \\
\text { ligands are flowed across the chip to } \\
\text { measure protein-protein, protein- } \\
\text { compounds, and protein-ligand binding } \\
\text { kinetics. }\end{array}$ & 45 \\
\hline $\begin{array}{l}\text { Transcripto } \\
\text { mic profiling }\end{array}$ & $10^{3}$ & $\begin{array}{l}\text { A gene signature captures the } \\
\text { transcriptomic changes in a disease } \\
\text { states or in response to a pertubagen, } \\
\text { such as compound treatment. }\end{array}$ & $\begin{array}{l}\text { Measured with sequencing or microarray } \\
\text { technologies - the methods differ based } \\
\text { on throughput, granularity, and cost. } \\
\text { Single cell sequencing is a comparatively } \\
\text { lower throughput, higher detailed and } \\
\text { more costly method than bulk RNA-seq } \\
\text { or low pass RNA-Seq. Low pass RNA- }\end{array}$ & $46-48$ \\
\hline
\end{tabular}


seq such as DRUG-seq, RASL-Seq, or L1000 enable a scalable platform. 
Supplementary Table 2 Commonly used reporter enzymes and properties.

\begin{tabular}{|c|c|c|c|c|c|c|}
\hline Enzyme & Species & $\begin{array}{l}\text { MW } \\
(\mathrm{kDa})\end{array}$ & $\begin{array}{l}\text { Em } \\
(\mathrm{nm})\end{array}$ & ATP & Substrate & Stability \\
\hline FLuc & Photinus pyralis & 62 & $550-570$ & Yes & D-luciferin & 4 hrs (cell) \\
\hline RFLuc $^{\mathrm{a}}$ & Luciola cruciata (mutant) & 62 & 620 & Yes & D-luciferin & $3.0 \mathrm{hrs}$ (cell) \\
\hline CBLuc & $\begin{array}{l}\text { Pyrophorus plagiophthalamus } \\
\text { (mutants) }\end{array}$ & 60 & $\begin{array}{l}537 \text { or } \\
613\end{array}$ & Yes & D-luciferin & 7 hrs (cell) \\
\hline UltraGlo $^{\mathrm{a}}$ & Photuris pennsylvanica (mutant) & 61 & $550-570$ & Yes & D-luciferin & $>24 \mathrm{hrs}$ at $60^{\circ} \mathrm{C}$ \\
\hline RLuc & Renilla reniformas & 36 & 480 & No & Coelenterazine & 4.5 hrs (cell) \\
\hline RLuc $^{\text {b }}$ & Renilla reniformas (mutant) & 36 & $480^{\mathrm{e}}$ & No & Coelenterazine & 4.5 hrs (cell) \\
\hline GRLuc $^{\mathrm{a}}$ & Renilla reniformas (mutant) & 36 & 530 & No & Coelenterazine & $>48$ hrs (cell) \\
\hline$\beta$-lactamase ${ }^{\mathrm{c}}$ & E. coli $($ TEM-1) & 29 & 520 & No & CCF2 & $3.5 \mathrm{hrs}$ (cell) \\
\hline NanoLuc ${ }^{\mathrm{d}}$ & Oplophorus gracilirostris & 19 & 450 & No & Furimazine & $\mathrm{T}_{\mathrm{M}}>60^{\circ} \mathrm{C}$ \\
\hline GLuc- & Gaussia princeps & 20 & 485 & No & Coelenterazine & $\begin{array}{l}60 \text { days in } \\
\text { supernatant }\end{array}$ \\
\hline TurboLuc & Metridia pacifica (mutant) & 15.7 & 480 & No & Coelenterazine & $1 \mathrm{hr}($ cell $)$ \\
\hline
\end{tabular}

${ }^{\mathrm{a} A}$ thermostable firefly luciferase developed by Promega for use in biochemical assay such as KinaseGlo or ADP Glo, or cytotoxicity assays such as Cell Titer Glo. ${ }^{\text {b}}$ The emission of RLuc8 can be blueshifted to $395 \mathrm{~nm}$ using DeepBlueC (coelenterazine-400a). ${ }^{c}$ Fluorescent reporter enzyme using the FRET substrate CCF2 - excitation wavelength 450nm, emission wavelength 520nm. ${ }^{\mathrm{d}}$ NanoLuc developed by Promega Corp. 


\section{Supplementary Table 3 Definitions of automated microscopes used for high content screening}

\begin{tabular}{|c|c|}
\hline Term & Description \\
\hline Widefield & $\begin{array}{l}\text { Widefield HCI systems operate in a manner similar to that of a typical manual inverted } \\
\text { laboratory microscope, and acquire images with a relatively thick depth of field (DoF) } \\
\text { when compared to confocal instruments with analogous optical configurations. The } \\
\text { relatively thick DoF for widefield systems presents both benefits and drawbacks in a } \\
\text { screening context. High-background signal from light originating above or below the } \\
\text { desired focal plane can reduce the contrast and thus the effective resolution of the images, } \\
\text { requiring an additional post-processing deconvolution step. Conversely, the greater DoF } \\
\text { allows the instrument to capture more of the desired sample within a single focal plane } \\
\text { than would be possible with a confocal microscope with a comparable configuration }\end{array}$ \\
\hline Confocal & $\begin{array}{l}\text { Confocal microscopes are designed to collect light from thin sections at different focal } \\
\text { planes of a given sample. Due to the reduction in out-of-focus light, these optical sections } \\
\text { are typically much sharper than Widefield images, though they require longer exposure } \\
\text { times than techniques with thicker Depth of Field (DoF) and multiple focal planes per } \\
\text { field (typically known as a Z-stack) may be required for each sample. Multiple optical } \\
\text { sections can be assembled into a 3-dimensional image via post-processing. Acquisition } \\
\text { of multiple focal panes increases overall acquisition time per experiment, and can result } \\
\text { in significant photobleaching and phototoxicity in live cell assays, particularly when } \\
\text { multiple time points will be acquired. Many confocal HCI systems offer the ability to } \\
\text { switch between confocal and widefield acquisition formats on demand. }\end{array}$ \\
\hline MIP & $\begin{array}{l}\text { A Maximum Intensity Projections (MIP) })^{50} \text { is a type of Intensity Projection (IP), which } \\
\text { utilizes software-based post-processing method to merge the brightest pixels from } \\
\text { multiple focal planes to produce a } 2 \mathrm{D} \text { or representation of the sample. }\end{array}$ \\
\hline Resolution & $\begin{array}{l}\text { Resolution in HCI applications is effectively a measurement of the minimum physical } \\
\text { size of a feature which can be detected, and is dependent upon a number of factors, some } \\
\text { more intuitive than others. The ability to resolve biological features in the context of } \\
\text { digital microscopy requires that the image of the feature of interest represent } 3 \text { or more } \\
\text { pixels when projected on to the camera. Objective magnification and Numerical Aperture } \\
\text { (NA) are major components, as are camera bit rate (MP) \& sensitivity (QE), and } \\
\text { transmission medium (e.g. Air, Oil, Water), as well as the wavelength of light used to } \\
\text { illuminate the sample. Software-based post-processing deconvolution techniques can be } \\
\text { employed to further enhance image quality. }\end{array}$ \\
\hline
\end{tabular}


Supplementary Table 4: Useful links for HCI assay design and analysis

\begin{tabular}{|c|c|c|c|}
\hline Topic & $\begin{array}{c}\text { Topic \& } \\
\text { Description }\end{array}$ & $\underline{\text { Level }}$ & $\underline{\text { Link }}$ \\
\hline $\begin{array}{l}\text { Microsco } \\
\text { py basics }\end{array}$ & $\begin{array}{l}\text { microscopy } \\
\text { concepts; } \\
\text { interactive } \\
\text { tutorials }\end{array}$ & Novice & $\begin{array}{l}\text { https://www.microscopyu.com/microscopy-basics } \\
\text { https://www.olympus-lifescience.com/en/microscope- } \\
\text { resource/primer/anatomy/anatomy/ }\end{array}$ \\
\hline $\begin{array}{l}\text { Imaging } \\
\text { basics }\end{array}$ & $\begin{array}{l}\text { fluorescence } \\
\text { microscopy } \\
\text { concepts }\end{array}$ & Novice & https://www.chroma.com/knowledge-resources \\
\hline $\begin{array}{l}\text { HCI } \\
\text { Camera } \\
\text { basics }\end{array}$ & $\begin{array}{l}\text { Cameras \& } \\
\text { specifics }\end{array}$ & Novice & $\begin{array}{l}\text { https://camera.hamamatsu.com/jp/en/technical_guides/dissecting_cam } \\
\text { era/dissecting_camera02/index.html }\end{array}$ \\
\hline $\begin{array}{l}\text { Thermo } \\
\text { SpectraV } \\
\text { iewer }\end{array}$ & $\begin{array}{l}\text { Utility for } \\
\text { wavelengths of } \\
\text { dyes and probes }\end{array}$ & Novice & $\begin{array}{l}\text { https://www.thermofisher.com/us/en/home/life-science/cell- } \\
\text { analysis/labeling-chemistry/fluorescence-spectraviewer.html }\end{array}$ \\
\hline $\begin{array}{l}\text { Cell } \\
\text { Profiler }\end{array}$ & $\begin{array}{l}\text { Open source } \\
\text { image analysis }\end{array}$ & Novice & https://cellprofiler.org/ \\
\hline $\begin{array}{l}\text { Cell } \\
\text { Profiler: } \\
\text { Tutorials }\end{array}$ & $\begin{array}{l}\text { Tutorials for } \\
\text { HCI analysis } \\
\text { w/Cell Profiler }\end{array}$ & Novice & https://cellprofiler.org/tutorials/ \\
\hline $\begin{array}{l}\text { Cell } \\
\text { Profiler: } \\
\text { Forum }\end{array}$ & $\begin{array}{l}\text { Discussion } \\
\text { forum for Cell } \\
\text { Profiler }\end{array}$ & Novice & https://forum.image.sc/tags/c/image-analysis/6/cellprofiler \\
\hline $\begin{array}{l}\text { Cell } \\
\text { Profiler: } \\
\text { Wiki@Gi } \\
\text { tHub }\end{array}$ & $\begin{array}{l}\text { Cell Profiler } \\
\text { Wiki \& code } \\
\text { repository }\end{array}$ & Novice & https://github.com/CellProfiler/CellProfiler/wiki \\
\hline $\begin{array}{l}\text { Cell } \\
\text { Profiler: } \\
\text { Distribut } \\
\text { ed }\end{array}$ & $\begin{array}{l}\text { Cell Profiler at } \\
\text { large scale }\end{array}$ & Novice & https://github.com/CellProfiler/Distributed-CellProfiler/wiki \\
\hline $\begin{array}{l}\text { FIJI: } \\
\text { Home }\end{array}$ & $\begin{array}{l}\text { Open source } \\
\text { image analysis }\end{array}$ & $\begin{array}{l}\text { Interme } \\
\text { diate }\end{array}$ & https://imagej.net/Fiji \\
\hline $\begin{array}{l}\text { FIJI: } \\
\text { Forum }\end{array}$ & $\begin{array}{l}\text { Discussion } \\
\text { forum for FIJI }\end{array}$ & $\begin{array}{l}\text { Interme } \\
\text { diate }\end{array}$ & https://forum.image.sc/tags/c/image-analysis/6/fiji \\
\hline
\end{tabular}




\begin{tabular}{|l|l|l|l|}
\hline $\begin{array}{l}\text { Icy } \\
\text { Bioimage } \\
: \text { Home }\end{array}$ & $\begin{array}{l}\text { Image analysis, } \\
\text { visualization, } \\
\text { and informatics }\end{array}$ & $\begin{array}{l}\text { Interme } \\
\text { diate }\end{array}$ & http://icy.bioimageanalysis.org/ \\
\hline $\begin{array}{l}\text { Omero: } \\
\text { Home }\end{array}$ & $\begin{array}{l}\text { Data analysis; } \\
\text { supports Cell } \\
\text { Profiler \& FIJI }\end{array}$ & $\begin{array}{l}\text { Advanc } \\
\text { ed }\end{array}$ & https://www.openmicroscopy.org/omero/ \\
\hline $\begin{array}{l}\text { Omero: } \\
\text { Guide }\end{array}$ & $\begin{array}{l}\text { Tutorials, and } \\
\text { plugins }\end{array}$ & $\begin{array}{l}\text { Advanc } \\
\text { ed }\end{array}$ & $\underline{\text { https://omero-guides.readthedocs.io/en/latest/ }}$ \\
\hline
\end{tabular}


Supplementary Table 5

\begin{tabular}{|c|c|}
\hline & Definition \\
\hline Hit & $\begin{array}{l}\text { A compound sample that effects the readout of an assay in a statistically significant manner (e.g. } \\
\text { 3. s.d. of the untreated samples). Many hits are often due to assay interferences requiring the } \\
\text { use of counter and orthogonal assays to confirm the activity of interest. A fraction of hits may } \\
\text { also be due to the sample tested and not the compound concept itself due to metal contaminants } \\
\text { or degradation of the compound sample. }\end{array}$ \\
\hline Validated hit & $\begin{array}{l}\text { In target-based assays, a hit is validated when shown to bind to the intended target through a } \\
\text { desired mechanism using affinity measurements. In cell-based assays, hit validation is } \\
\text { demonstrated when a hit is shown to genuinely effect the activity of interest (e.g. pathway } \\
\text { response or pharmacodynamic (PD) marker). }\end{array}$ \\
\hline Lead & $\begin{array}{l}\text { A compound or compound series that reproducibly effects the biology of interest through } \\
\text { rigorous testing in project specific assays. Chemical matter is tractable to develop structure- } \\
\text { activity relationships in relevant assays and progress toward desired lead criteria such as } \\
\text { potency, selectivity, cellular activity, intestinal cellular absorption, and metabolic stability }\end{array}$ \\
\hline $\begin{array}{l}\text { Preclinical } \\
\text { candidate }\end{array}$ & $\begin{array}{l}\text { A compound derived from a Lead that fits the target project profile for the primary disease } \\
\text { indication. The profile includes criteria for physicochemical properties that are suitable for } \\
\text { dosing patients, potency, efficacy, selectivity, and safety criteria. Preclinical candidates are filed } \\
\text { as investigational new drugs (IND) and if approved advance to testing in humans starting with } \\
\text { Phase I safety trials. }\end{array}$ \\
\hline
\end{tabular}




\section{Supplemental References}

1. Eglen, R. M., Reisine, T., Roby, P., et al. (2008) The use of AlphaScreen technology in HTS: current status, Curr Chem Genomics 1, 2-10 DOI: 10.2174/1875397300801010002.

2. O'Connell, T. N., Ramsay, J., Rieth, S. F., et al. (2014) Solution-Based Indirect Affinity Selection Mass Spectrometry-A General Tool For High-Throughput Screening Of Pharmaceutical Compound Libraries, Anal Chem 86, 7413-7420 DOI: 10.1021/ac500938y.

3. Annis, D. A., Nickbarg, E., Yang, X., et al. (2007) Affinity selection-mass spectrometry screening techniques for small molecule drug discovery, Curr Opin Chem Biol 11, 518-526 DOI: 10.1016/j.cbpa.2007.07.011.

4. Moree, B., Connell, K., Mortensen, R. B., et al. (2015) Protein Conformational Changes Are Detected and Resolved Site Specifically by Second-Harmonic Generation, Biophys J 109, 806-815 DOI: 10.1016/j.bpj.2015.07.016.

5. Bertrand, L., Parent, S., Caron, M., et al. (2002) The BRET2/arrestin assay in stable recombinant cells: A platform to screen for compounds that interact with G protein-coupled receptors (GPCRS), $J$ Recept Signal Tr R 22, 533-541 DOI: 10.1081/Rrs-120014619.

6. Seashore-Ludlow, B., and Lundback, T. (2016) Early Perspective: Microplate Applications of the Cellular Thermal Shift Assay (CETSA), J Biomol Screen 21, 1019-1033 DOI: $10.1177 / 1087057116659256$.

7. Jafari, R., Almqvist, H., Axelsson, H., et al. (2014) The cellular thermal shift assay for evaluating drug target interactions in cells, Nature Protocols 9, 2100-2122 DOI: 10.1038/nprot.2014.138.

8. Bergsdorf, C., and Wright, S. K. (2018) A Guide to Run Affinity Screens Using Differential Scanning Fluorimetry and Surface Plasmon Resonance Assays, Method Enzymol 610, 135-165 DOI: 10.1016/bs.mie.2018.09.015.

9. Thomson, J. A., Itskovitz-Eldor, J., Shapiro, S. S., et al. (1998) Embryonic stem cell lines derived from human blastocysts, Science 282, 1145-1147 DOI: 10.1126/science.282.5391.1145.

10. Lin, H. C., Yeh, C. W., Chen, Y. F., et al. (2018) C-Terminal End-Directed Protein Elimination by CRL2 Ubiquitin Ligases, Mol Cell 70, 602-+ DOI: 10.1016/j.molcel.2018.04.006.

11. Lu, G., Middleton, R. E., Sun, H. H., et al. (2014) The Myeloma Drug Lenalidomide Promotes the Cereblon-Dependent Destruction of Ikaros Proteins, Science 343, 305-309 DOI: 10.1126/science.1244917.

12. Wang, C. S., Niederstrasser, H., Douglas, P. M., et al. (2017) Small-molecule TFEB pathway agonists that ameliorate metabolic syndrome in mice and extend C-elegans lifespan, Nature Communications 8 DOI: ARTN 2270

10.1038/s41467-017-02332-3. 
13. Yen, H. C. S., Xu, Q. K., Chou, D. M., et al. (2008) Global Protein Stability Profiling in Mammalian Cells, Science 322, 918-923 DOI: 10.1126/science.1160489.

14. Boettcher, A., Gradoux, N., Lorthiois, E., et al. (2014) Fluorescence Lifetime-Based Competitive Binding Assays for Measuring the Binding Potency of Protease Inhibitors In Vitro, J Biomol Screen 19, 870-877 DOI: 10.1177/1087057114521295.

15. Lea, W. A., and Simeonov, A. (2011) Fluorescence polarization assays in small molecule screening, Expert Opin Drug Dis 6, 17-32 DOI: 10.1517/17460441.2011.537322.

16. Algar, W. R., Hildebrandt, N., Vogel, S. S., et al. (2019) FRET as a biomolecular research toolunderstanding its potential while avoiding pitfalls, Nat Methods 16, 815-829 DOI: 10.1038/s41592-019-0530-8.

17. Degorce, F., Card, A., Soh, S., et al. (2009) HTRF: A technology tailored for drug discovery - a review of theoretical aspects and recent applications, Curr Chem Genomics 3, 22-32 DOI: $10.2174 / 1875397300903010022$.

18. Jost, A. P., and Waters, J. C. (2019) Designing a rigorous microscopy experiment: Validating methods and avoiding bias, J Cell Biol 218, 1452-1466 DOI: 10.1083/jcb.201812109.

19. Buchser, W., Collins, M., Garyantes, T., et al. (2004) Assay Development Guidelines for Image-Based High Content Screening, High Content Analysis and High Content Imaging, In Assay Guidance Manual (Sittampalam, G. S., Grossman, A., Brimacombe, K., Arkin, M., Auld, D., Austin, C. P., Baell, J., Bejcek, B., Caaveiro, J. M. M., Chung, T. D. Y., Coussens, N. P., Dahlin, J. L., Devanaryan, V., Foley, T. L., Glicksman, M., Hall, M. D., Haas, J. V., Hoare, S. R. J., Inglese, J., Iversen, P. W., Kahl, S. D., Kales, S. C., Kirshner, S., Lal-Nag, M., Li, Z., McGee, J., McManus, O., Riss, T., Saradjian, P., Trask, O. J., Jr., Weidner, J. R., Wildey, M. J., Xia, M., and Xu, X., Eds.), Bethesda (MD).

20. Rohman, M., and Wingfield, J. (2016) High-Throughput Screening Using Mass Spectrometry within Drug Discovery, Methods Mol Biol 1439, 47-63 DOI: 10.1007/978-1-4939-3673-1_3.

21. Joslin, J., Gilligan, J., Anderson, P., et al. (2018) A Fully Automated High-Throughput Flow Cytometry Screening System Enabling Phenotypic Drug Discovery, Slas Discov 23, 697-707 DOI: $10.1177 / 2472555218773086$.

22. Wilson, A. C., Moutsatsos, I. K., Yu, G., et al. (2018) A Scalable Pipeline for High-Throughput Flow Cytometry, Slas Discov 23, 708-718 DOI: 10.1177/2472555218774770.

23. Takahashi, K., Okita, K., Nakagawa, M., et al. (2007) Induction of pluripotent stem cells from fibroblast cultures, Nat Protoc 2, 3081-3089 DOI: 10.1038/nprot.2007.418.

24. Chen, H., Zhang, A., and Wu, J. C. (2018) Harnessing cell pluripotency for cardiovascular regenerative medicine, Nat Biomed Eng 2, 392-398 DOI: 10.1038/s41551-018-0244-8.

25. Corbett, J. L., and Duncan, S. A. (2019) iPSC-Derived Hepatocytes as a Platform for Disease Modeling and Drug Discovery, Front Med (Lausanne) 6, 265 DOI: 10.3389/fmed.2019.00265. 
26. Fujita, A., Uchida, N., Haro-Mora, J. J., et al. (2016) beta-Globin-Expressing Definitive Erythroid Progenitor Cells Generated from Embryonic and Induced Pluripotent Stem Cell-Derived Sacs, Stem Cells 34, 1541-1552 DOI: 10.1002/stem.2335.

27. Lin, Y., Gil, C. H., and Yoder, M. C. (2017) Differentiation, Evaluation, and Application of Human Induced Pluripotent Stem Cell-Derived Endothelial Cells, Arterioscler Thromb Vasc Biol 37, 20142025 DOI: 10.1161/ATVBAHA.117.309962.

28. Shoji, E., Woltjen, K., and Sakurai, H. (2016) Directed Myogenic Differentiation of Human Induced Pluripotent Stem Cells, Methods Mol Biol 1353, 89-99 DOI: 10.1007/7651_2015_257.

29. Takata, K., Kozaki, T., Lee, C. Z. W., et al. (2017) Induced-Pluripotent-Stem-Cell-Derived Primitive Macrophages Provide a Platform for Modeling Tissue-Resident Macrophage Differentiation and Function, Immunity 47, 183-198 e186 DOI: 10.1016/j.immuni.2017.06.017.

30. Zhao, P., Zhu, T., Lu, X., et al. (2015) Neurogenin 2 enhances the generation of patient-specific induced neuronal cells, Brain Res 1615, 51-60 DOI: 10.1016/j.brainres.2015.04.027.

31. Haslam, C., Hellicar, J., Dunn, A., et al. (2016) The Evolution of MALDI-TOF Mass Spectrometry toward Ultra-High-Throughput Screening: 1536-Well Format and Beyond, J Biomol Screen 21, 176-186 DOI: $10.1177 / 1087057115608605$.

32. Thorne, N., Shen, M., Lea, W. A., et al. (2012) Firefly Luciferase in Chemical Biology: A Compendium of Inhibitors, Mechanistic Evaluation of Chemotypes, and Suggested Use As a Reporter, Chem Biol 19, 1060-1072 DOI: 10.1016/j.chembiol.2012.07.015.

33. Ho, P. I., Yue, K., Pandey, P., et al. (2013) Reporter Enzyme Inhibitor Study To Aid Assembly of Orthogonal Reporter Gene Assays, Acs Chem Biol 8, 1009-1017 DOI: 10.1021/cb3007264.

34. Zlokarnik, G., Negulescu, P. A., Knapp, T. E., et al. (1998) Quantitation of transcription and clonal selection of single living cells with beta-lactamase as reporter, Science 279, 84-88 DOI: DOI 10.1126/science.279.5347.84.

35. Hall, M. P., Unch, J., Binkowski, B. F., et al. (2012) Engineered Luciferase Reporter from a Deep Sea Shrimp Utilizing a Novel Imidazopyrazinone Substrate, Acs Chem Biol 7, 1848-1857 DOI: $10.1021 / \mathrm{cb} 3002478$.

36. Dixon, A. S., Schwinn, M. K., Hall, M. P., et al. (2016) NanoLuc Complementation Reporter Optimized for Accurate Measurement of Protein Interactions in Cells, Acs Chem Biol 11, 400-408 DOI: 10.1021/acschembio.5b00753.

37. Robers, M. B., Dart, M., Zimprich, C., et al. (2015) Measuring intracellular target engagement and drug residence time with nanoBRET, Cancer Res 75 DOI: 10.1158/1538-7445.Am2015-3512.

38. Machleidt, T., Woodroofe, C. C., Schwinn, M. K., et al. (2015) NanoBRET-A Novel BRET Platform for the Analysis of Protein-Protein Interactions, Acs Chem Biol 10, 1797-1804 DOI: 10.1021/acschembio.5b00143. 
39. Dart, M. L., Machleidt, T., Jost, E., et al. (2018) Homogeneous Assay for Target Engagement Utilizing Bioluminescent Thermal Shift, Acs Med Chem Lett 9, 546-551 DOI: 10.1021/acsmedchemlett.8b00081.

40. Seidel, S. A. I., Dijkman, P. M., Lea, W. A., et al. (2013) Microscale thermophoresis quantifies biomolecular interactions under previously challenging conditions, Methods 59, 301-315 DOI: 10.1016/j.ymeth.2012.12.005.

41. Tyagi, S., and Kramer, F. R. (1996) Molecular beacons: Probes that fluoresce upon hybridization, Nat Biotechnol 14, 303-308 DOI: DOI 10.1038/nbt0396-303.

42. Abdelkarim, H., Hitchinson, B., Banerjee, A., et al. (2019) Advances in NMR Methods to Identify Allosteric Sites and Allosteric Ligands, Adv Exp Med Biol 1163, 171-186 DOI: 10.1007/978-98113-8719-7_8.

43. Viegas, A., Manso, J., Nobrega, F. L., et al. (2011) Saturation-Transfer Difference (STD) NMR: A Simple and Fast Method for Ligand Screening and Characterization of Protein Binding, $J$ Chem Educ 88, 990-994 DOI: 10.1021/ed101169t.

44. Huang, R. J., and Leung, I. K. H. (2019) Protein-Small Molecule Interactions by WaterLOGSY, Biological Nmr, Pt B 615, 477-500 DOI: 10.1016/bs.mie.2018.08.020.

45. Huber, W., and Mueller, F. (2006) Biomolecular interaction analysis in drug discovery using surface plasmon resonance technology, Curr Pharm Design 12, 3999-4021 DOI: Doi $10.2174 / 138161206778743600$.

46. Subramanian, A., Narayan, R., Corsello, S. M., et al. (2017) A Next Generation Connectivity Map: L1000 Platform and the First 1,000,000 Profiles, Cell 171, 1437-+ DOI: 10.1016/j.cell.2017.10.049.

47. Li, H., Qiu, J., and Fu, X. D. (2012) RASL-seq for massively parallel and quantitative analysis of gene expression, Curr Protoc Mol Biol Chapter 4, Unit 413 11-19 DOI: 10.1002/0471142727.mb0413s98.

48. Ye, C. Y., Ho, D. J., Neri, M., et al. (2018) DRUG-seq for miniaturized high-throughput transcriptome profiling in drug discovery, Nature Communications 9 DOI: ARTN 4307

10.1038/s41467-018-06500-x.

49. (2020) Microscopy U, https://www.microscopyu.com/microscopy-basics/depth-of-field-and-depth-offocus.

50. Shihavuddin, A., Basu, S., Rexhepaj, E., et al. (2017) Smooth 2D manifold extraction from 3D image stack, Nature Communications 8 DOI: ARTN 15554

10.1038/ncomms15554. 